\title{
Plant Species Richness and Non-Native InVASIONS IN FIVE RIPARIAN COMMUNITIES IN Grand Teton National Park, WyOMing
}

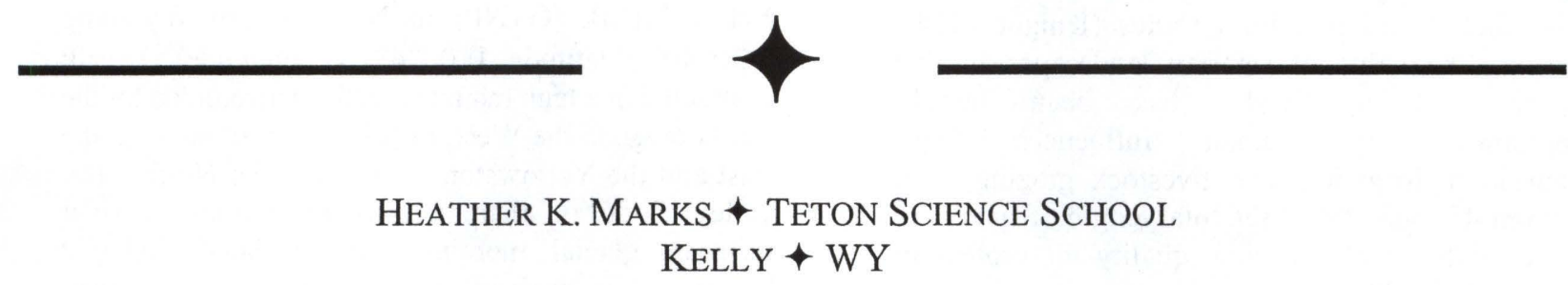

\section{+ ABSTRACT}

Non-native species invasions in national parks directly interfere with the major management goal of protecting native biota. The status of species richness and non-native invasions was assessed in five riparian vegetation types in Grand Teton National Park, Wyoming, with nested-scale number and frequency vegetation data using a ModifiedWhittaker sampling design. In the $20\left(1000-\mathrm{m}^{2}\right)$ plots sampled, non-native species represented $11.9 \%$ (35) of the total 294 species recorded. Non-native species were found in small populations either widely dispersed across the five vegetation types or appearing to have some level of habitat specificity.

Total species richness across the five vegetation types varied from 42 species in the sage community to 96 species in the conifer-broadleaf community. Overall, mean species richness across the five communities was 81.9 species/0.1 ha. A suite of environmental variables such as nutrient availability, flood regime, herbivory as well as successional trends may explain the variability in species richness across communities.

Patterns of total species richness across multiple scales were fairly consistent. Patterns of non-native species invasion, however, appeared to be both scale and vegetation type dependent. The highest proportion of non-native species for four of the five vegetation types was recorded at the smaller sampling scales. The alder community was the most invaded at all scales measured and had the most distinct assemblage of non-native species.

Some studies suggest that community invasibility may be related to species richness. At the $1-\mathrm{m}^{2}$ and $1000-\mathrm{m}^{2}$ scales, total species richness and number of non-native species were significantly and positively correlated. When the alder sites were removed from analysis at the $1000-\mathrm{m}^{2}$ scale, the positive linear relationship increased, and the total variance explained by the linear models was enhanced by $38 \%$. At all scales sampled, the alder sites were highly and disproportionately invaded, often more than twice the level of other communities. The mechanism of nitrogen fixation may be promoting non-native invasions in the alder community.

At the vegetation type scale (combined species lists from four $1000-\mathrm{m}^{2}$ plots in each community), those communities with the most unique non-native assemblages were the most invaded. A significant negative linear relationship between nonnative species overlap and percentage of non-native species was observed in the alder sites at each scale sampled. This pattern suggests some relationship between properties of an invading species and properties of the community that it invades.

Because the results of this study suggest species rich riparian landscapes are vulnerable to non-native invasions, recommendations are offered to assist managers in responding efficiently and effectively to this conservation priority. 


\section{INTRODUCTION}

Because of their rich and often unique assemblages of plant and animal species (Décamps and Tabacchi 1994), riparian landscapes are important for regional biodiversity. Riparian habitats have an ecological, cultural, and economic importance far beyond their relatively small area across a landscape. For example, in Wyoming $\leq 1 \%$ of the region is classified as riparian while an estimated $80 \%$ of native animals depend, at some time during the year, on this limited area for food, water, shelter and migration routes (Knight 1994). However, the value of riparian landscapes in this country, and worldwide, has been largely compromised by human influences (e.g., urbanization, irrigation, and livestock grazing). In the lower 48 , only $2 \%$ of the total length of rivers are considered to be of sufficient quality for protection (Naiman et al. 1993).

Recent studies indicate that species-rich, productive riparian zones are particularly vulnerable to non-native species invasion in many ecosystems (Stohlgren et al. 1998a); Planty-Tabacchi et al. 1996). There is a long history of the idea that disturbance influences invasibility of a community (Huston 1994). It has also been suggested that invasions may be related to species richness (Planty-Tabacchi et al. 1996). Beyond the original observation of Elton (1958) and others (Fox and Fox 1986; Huston 1994), that species-poor communities may be more prone to invasion, it is now hypothesized that species rich communities may use limiting resources more completely and prevent invasion from competing non-native species (Fox and Fox 1986; Tilman 1997). Mathematical models also suggest species rich areas should be resistant to invasion (Case 1990). Recent field studies, however, suggest that invasibility may be proportional to species richness (Planty-Tabacchi et al. 1996). Species rich communities that receive an intermediate level of disturbance (fire, flood, herbivory) may have more resources available for invading species (Stohlgren et al. 1998b). Others have suggested unexploited resources and available space are not requisite for non-native invasions. In this scenario, the non-native species are assumed to replace the resident ones (Crawley 1987).

Structurally diverse, productive, and dynamic riparian landscapes may provide crucial insight into the relationships between native species richness and the presence of non-native species. In order to assess the patterns of species richness and non-native invasion in five riparian vegetation types in Grand Teton National Park, field research was conducted to address the following questions: (1) How does native, non-native and total species richness vary across five vegetation types at multiple scales?; and (2) What is the relationship between total species richness and non-native invasion?

\section{METHODS}

Study Area

The study area is located in Grand Teton National Park (GTNP) in Northwestern Wyoming ( $43^{\circ} 40^{\prime} \mathrm{N}$ latitude, $110^{\circ} 43^{\prime} \mathrm{W}$ longitude). GTNP is situated in a high mountain valley surrounded by the Teton range to the West, the Gros Ventre range to the East and the Yellowstone Plateau to the North. The valley floor is characterized by numerous river terraces, glacial moraines, and isolated timbered buttes. It is drained chiefly by the Snake River, which bisects the valley and supports its largest riparian community. The Snake River corridor is characterized by well-developed, geomorphically complex floodplains with long periods of seasonal flooding, lateral channel migration, oxbow lakes in old river channels, diverse vegetation communities, and moist soils. Elevation within GTNP ranges from $7000 \mathrm{ft}$. at the valley floor to almost $14,000 \mathrm{ft}$. at the mountain peaks. Long, cold winters and short cool summers characterize the climate.

The study site included an approximately 600 acre (234 ha) area of riparian landscape on the west bank of the Snake River near Moose. In the study area, the principal riparian vegetation types include sagebrush/bitterbrush shrubland (Artemisia tridentata Nutt. and $A$. arbuscula Nutt./Purshia tridentata (Pursh) DC.), conifer/broadleaf woodland containing stands of cottonwood (Populus angustifolia James), Colorado blue spruce (Picea pungens Englem.), lodgepole pine (Pinus contorta Dougl. ex Loud.), Alder woodland (Alnus incana (L.) Moench), mixed conifer woodland including $P$. contorta, $P$. pungens, Douglas-fir (Pseudotsuga mensiezii (Mirb.) Franco), and subalpine fir (Abies lasiocarpa (Hook.) Nutt.), willow shrubland (Salix spp.), and riparian meadows (Knight 1994).

\section{Unbiased Site Selection}

Sample plots were randomly placed in five vegetation types using 1:12000 natural color aerial photographs taken on 6 October 1996, and stratifiedrandom sampling design. Based on photo interpretation, vegetation was stratified to include 
homogeneous and heterogeneous (e.g., ecotones, mixed stands) plant communities. After completing a general floristic survey and ground-truthing of the mapped vegetation communities, four plot locations in each vegetation type were randomly selected using a grid system on a plastic overlay atop the aerial photograph. The plots were located with the aid of photographs, maps, and compass, and then mapped with a global positioning system.

\section{Multi-scale Vegetation Sampling}

The methodology closely follows that of Stohlgren et al. (1997). At each sampling point, a Modified-Whittaker (M-W) nested vegetation sampling plot $(20 \mathrm{~m} \times 50 \mathrm{~m}$, ) was placed across the major environmental gradient (Fig. 3). Nested within each plot were ten $0.5 \mathrm{~m} \times 2 \mathrm{~m}\left(1 \mathrm{~m}^{2}\right)$ subplots arranged systematically inside and adjacent to the plot perimeter, two $2 \mathrm{~m} \times 5 \mathrm{~m}\left(10 \mathrm{~m}^{2}\right)$ subplots in diagonal corners, and one $5 \mathrm{~m} \times 20 \mathrm{~m}\left(100 \mathrm{~m}^{2}\right)$ subplot in the center of the plot. Foliar cover for each species and five non-vegetative characteristics (rock, litter, bare ground, scat, and down wood) were estimated to the nearest $1 \%$ in the ten $1 \mathrm{~m}^{2}$ subplots, and cumulative species were successively recorded in the $10 \mathrm{~m}^{2}$, $100 \mathrm{~m}^{2}$ subplots, and $1000 \mathrm{~m}^{2}$ plots. Ancillary data recorded at each plot included slope, aspect, latitude/longitude location from a g lobal positioning system, and elevation from 7.5 minute topographic maps.

The $20 \mathrm{~m} \times 50 \mathrm{~m}$ plot size has been widely used throughout the world facilitating comparison between regions (Baker 1990). The M-W nested plot minimizes design flaws of other nested sampling methods (Stohlgren et al. 1995) and returns significantly higher species richness values than other vegetation sampling techniques (Stohlgren et al. 1998b). This design was also shown to be robust across a range of habitats, vegetation types, and land use characteristics (Stohlgren et al. 1998b).

Sampling in each community was conducted as close to the peak plant phenology as possible between the dates of 25 July and 3 August 1999. Plant species that could not be identified in the field were collected and identified on site (following Dorn (1992)) and Hitchcock and Cronquist (1973) or at the University of Wyoming, Rocky Mountain Herbarium in Laramie. Nomenclature follows Nelson and Hartman (1997).

Species richness for each vegetation type was determined by combining species lists from replicate plots and removing duplicate entries.
Jaccard's coefficient $(\mathrm{J})$ was used to measure the degree of overlap between the combined species list for the five riparian vegetation types as follows: $\mathrm{J}=\mathrm{A} /(\mathrm{A}+\mathrm{B}+\mathrm{C})$, where $\mathrm{A}=$ the number of species found in both paired vegetation types; $\mathrm{B}=$ species in type 1 but not in type 2; and C = species in type 2 but not in type 1 (Stohlgren et al. 1998a). A comparison of species lists for two types resulting in a coefficient of 1.0 would indicate complete similarity (i.e., identical species lists), while a value of 0 would indicate dissimilar sites with no species in common.

\section{Statistical Analysis}

The unit of analysis is the number of species observed designating species richness. Differences in the number of total, native, and non-native species among the five vegetation types were tested using ANOVA followed by post hoc Tukey multiple comparisons. Simple linear regression was used to measure the relationship of total species richness and exotic species richness as well as the relationship between species overlap and the percentage of nonnative species observed. SYSTAT version 7.0 (Wilkinson 1997) was used to perform statistical analysis.

\section{RESULTS}

Plant Species Richness Across Five Riparian Vegetation Types

In the 20 sites sampled in the alder, conifer, conifer-broadleaf, cottonwood, and sage vegetation types, 294 total plant species were recorded. Fortynine families and 185 genera were represented. Native species represented $88.1 \%$ of the total flora (259 species), and $11.9 \%$ of species ( 35 species) were non-native in origin. The National Park Service defines non-native species as "those that occur in a given place as a result of direct or indirect, deliberate or accidental action by humans" (Rutledge and McLendon); Table 1. Seven "Species of Special Concern" in Wyoming (Table 2) and six non-native species prioritized for management in Grand Teton National Park (Table 3) were recorded. Forbs and graminoids were the dominant functional groups, accounting for $69.7 \%$ and $19.4 \%$ of the total species, respectively. Shrubs and trees accounted for just over $10 \%$ of the total species. 


\begin{tabular}{|lcc|}
\hline \multicolumn{3}{|c|}{$\begin{array}{l}\text { Table 1. Study area species richness } \\
\text { characteristics. }\end{array}$} \\
\hline Category & No. Species & \% of Total Richness \\
\hline Forbs & 205 & 69.7 \\
Graminoids & 57 & 19.4 \\
Shrubs & 23 & 7.8 \\
Trees & 9 & 3.1 \\
\hline Total Species & 294 & 100 \\
& & \\
& & \\
& & \\
Category & Species & Richness \\
\hline Native & 259 & 88.1 \\
Species & & 11.9 \\
Non-Native & & 100 \\
Species & 35 & \\
\hline Total Species & 294 & \\
\hline
\end{tabular}

Table 2. Mean percent frequency of native "Species of Special Concern" in Wyoming across five riparian vegetation types. $\mathrm{N}=56$ total subplots in each vegetation type.

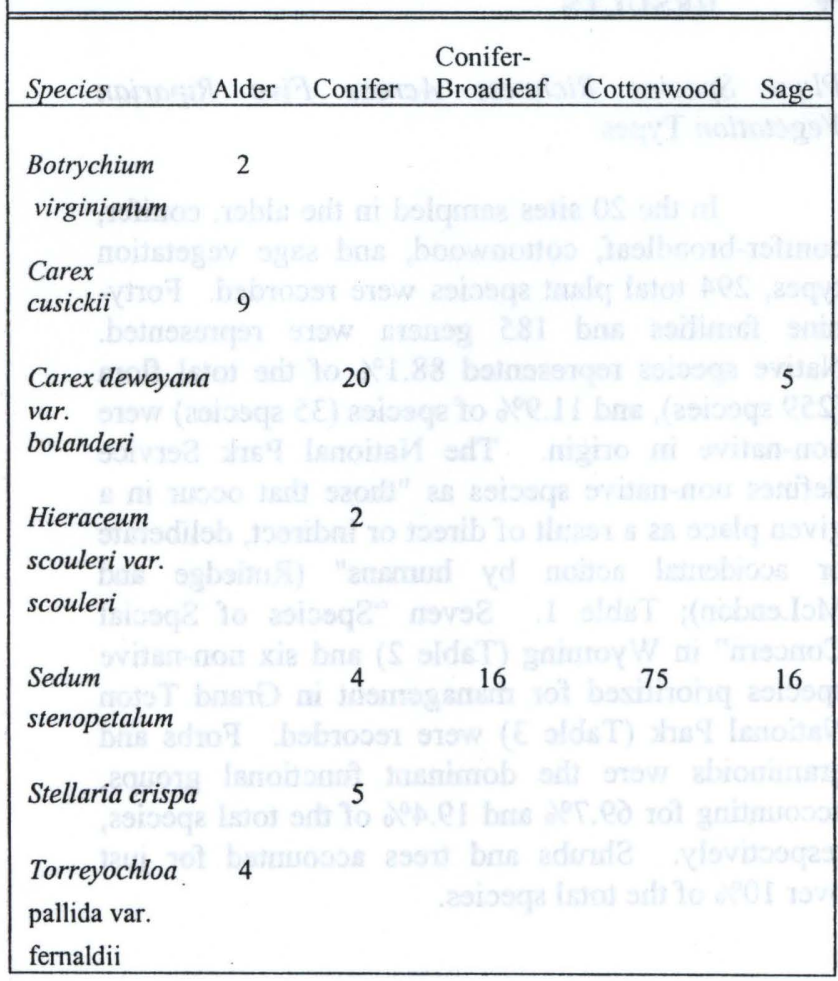

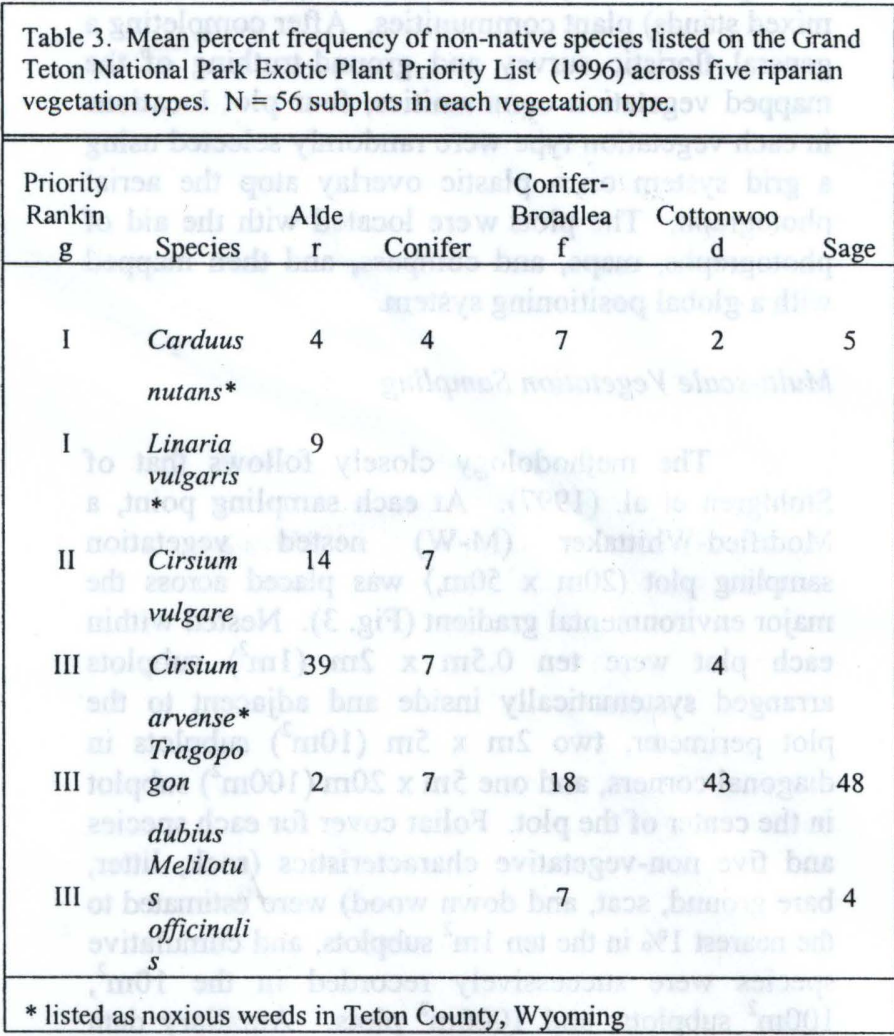

Total species richness varied considerably across the five communities. At the vegetation type scale (combined species lists from four $1000 \mathrm{~m}^{2}$ plots per type), total species richness ranged from 176 species in the conifer-broadleaf type to 118 species in the sage type (Table 4). At this scale, the coniferbroadleaf community had the highest number of total, native, and non-native species, but had a lower percentage of non-native species than the alder, conifer, and cottonwood types. The alder community, relatively low in total species richness, was highly invaded $(16.3 \%)$ compared to all other vegetation types (Table 4).

At the $1 \mathrm{~m}^{2}$ scale, total and native species richness in the conifer sites were significantly greater than all other vegetation types $(P<0.001$, Table $5 \mathrm{~A})$. Although lowest in native species richness, the alder sites had the highest mean number of non-native species ( $2.15 \pm 0.20$ species), and were significantly more invaded than all other vegetation types $(P<$ 0.001 , Table $5 \mathrm{~A}$ ). At the $1 \mathrm{~m}^{2}$ scale, non-native species comprised $18.7 \%$ of the total species richness in the alder sites, more than twice the level in the cottonwood sites $(8.2 \%)$. Significant relationships 
between communities according to total, native, and non-native species richness and percent invasion were similar at the $10 \mathrm{~m}^{2}$ and $100 \mathrm{~m}^{2}$ scales (Table $5 B)$.
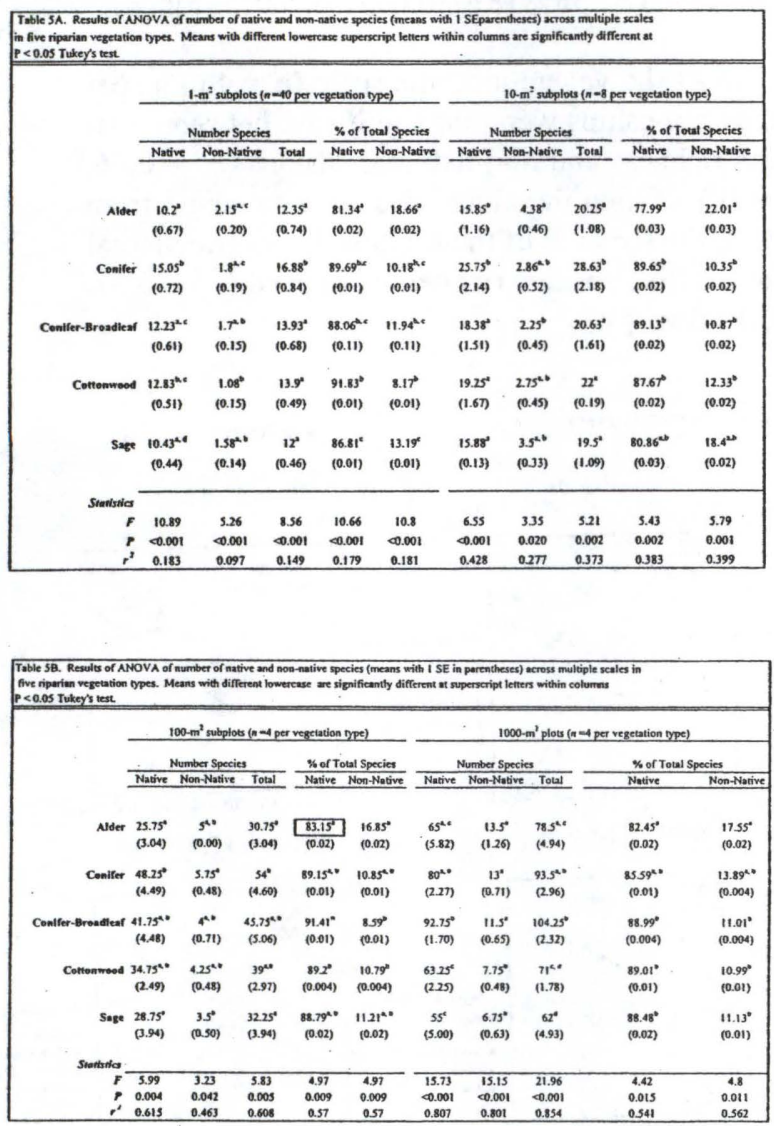

Several general observations about species abundance, distribution, and specific species associations with vegetation types a re worth noting. The most commonly r ecorded non-native species in all 20 sample plots were Poa pratensis L. and Taraxacum spp. (mean frequency $\geq 50 \%$ ) and, to a lesser extent, Tragopogon dubius Scop. (mean frequency $24 \%$ ). These three species were the primary invaders in the conifer-broadleaf, cottonwood, and sage communities. Lepidium virginicum var. pubescens (Greene) C.L. Hitche was most abundant and evenly distributed in the sage and cottonwood vegetation types (mean frequency $\geq$ 14\%). Chenopodium album var. album L., Lactuca oblogifolia Nutt., Phleum pratense L., and Trifolium pratense L. were common (yet patchy) in the coniferbroadleaf community (mean frequency $\geq 11 \%$ ). Galium aparine L. was most abundant and widely distributed across the conifer and alder sites (mean frequency $\geq 41 \%$ ).
Several non-native plants were unique to specific communities and plot locations (Table 7). The alder sites had the most distinctive assemblage of non-native species, with a total of six species found only in this vegetation type. The conifer and coniferbroadleaf communities each had two non-native species unique to those sites, and the cottonwood community had one species found in no other vegetation type. Frequency of these plants across the four sample plots varied widely (Table 7).

Table 7. Mean percent frequency of habitat specific non-native species.

\begin{tabular}{|c|c|}
\hline Vegetation Type/Species & Mean \% Frequency \\
\hline \multicolumn{2}{|l|}{ Alder } \\
\hline Arenaria serpyllifolia & 20 \\
\hline Linaria vulgaris* & 9 \\
\hline Potentilla norvegica & 14 \\
\hline Potentilla recta & 13 \\
\hline Rumex crispus & 4 \\
\hline Saponaria officinalis & 4 \\
\hline \multicolumn{2}{|l|}{ Conifer } \\
\hline Phalaris arundinacea & 2 \\
\hline Trifolium hybridum & 4 \\
\hline \multicolumn{2}{|l|}{ Conifer-Broadleaf } \\
\hline Medicago sativa & 2 \\
\hline Melilotus officinalis * & 4 \\
\hline \multicolumn{2}{|l|}{ Cottonwood } \\
\hline Agropyrom cristatum & 5 \\
\hline
\end{tabular}

The six non-native species on the GTNP priority list had some notable frequencies and distributions (Table 3). Carduus nutans L. and Tragopogon dubuis were recorded in all five vegetation types - the former having consistently low frequencies across vegetation types (mean frequency $\leq 7 \%$ ), and the latter having disproportionately high frequencies in the cottonwood and sage communities (mean frequency $\geq 43 \%$ ). Cirsium arvense (L.) Scop. was observed in three of the five vegetation types with distributions heavily concentrated in three alder sites. Priority non-native species unique to the alder and c onifer-broadleaf c ommunities i ncluded Linaria vulgaris Mill. and Melilotus officinalis (L.) Pallas. Cirsium vulgare (Savi) Tenore was found almost exclusively in the alder sites, being observed in only one other conifer sample plot. 
Relationships Between Species Richness and NonNative Invasions

At the $1 \mathrm{~m}^{2} \mathrm{~s}$ cale, positive linear regression models best describe the relationship between total species richness and number of non-native plant species in these Snake River riparian vegetation types. Total species richness and number of nonnative species were positively correlated in four of the five vegetation types (Fig. 3). The positive linear relationships were strongest for the conifer and conifer-broadleaf communities $\left(r^{2}=0.05, P<0.001\right.$ and $r^{2}=0.25, P<0.002$, respectively), and weaker for the sage type $\left(r^{2}=0.12, P<0.03\right)$. When all vegetation types were combined, total and non-native species richness were positively and significantly correlated despite considerable variability in the scattergrams $\left(r^{2}=0.06, P<0.001\right.$, Fig. 3$)$. Only the alder community demonstrated a significant positive linear relationship between total species richness and percentage of non-native species $\left(r^{2}=0.12, P<\right.$ 0.032 ).
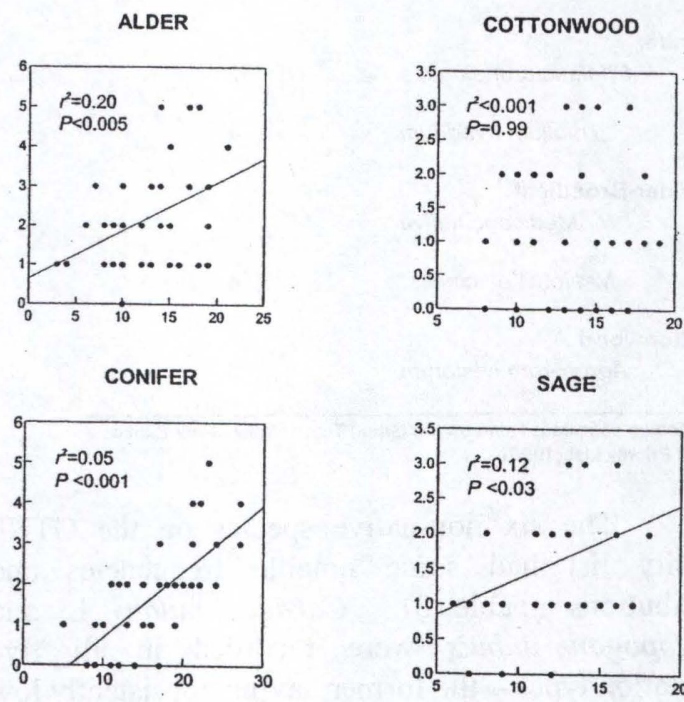

CONIFER-BROADLEAF

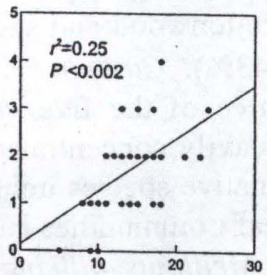

TOTAL SPECIES RICHNESS (NUMBER OF SPECIES)

Figure 3. Relationship of non-native species richness to total species richness in $1-\mathrm{m}^{2}$ subplots across five vegetation types. Coefficients of
subplots in each vegetation type.

Similarly, at the $1000 \mathrm{~m}^{2}$ scale, there was a significant positive linear relationship between total species richness and number of non-native species ( $r$ ${ }^{2}=0.31, P<0.02$, Fig. 4). When comparing models with all sites combined to those with the four a lder sites removed, positive linear relationships increased, and the total variance explained by the linear models was enhanced by $38 \%\left(r^{2}=0.69, P<0.001\right.$, Fig. 4$)$.

At the vegetation type scale $(n=4$ plots per type), relationships were not significant between total species richness and non-native invasions $\left(r^{2}=0.46\right.$, $P=0.20)$. When the alder sites were removed from analysis, the strength of the relationship between total and non-native species richness improved $\left(r^{2}=0.57\right.$, $P=0.14$, Fig. 4).

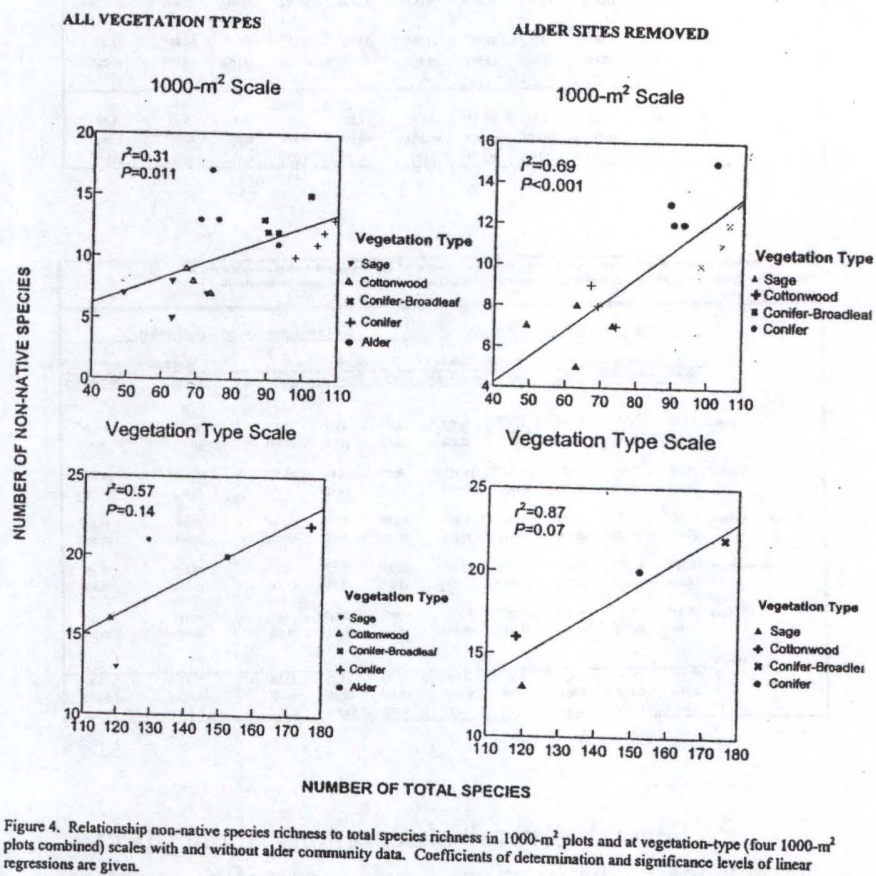

\section{Relationships Between Species Overlap and Non-} Native Invasions

Total species composition overlap between the five vegetation types varied considerably. At all scales sampled, the alder community had the most unique total species, ranging from $13 \%$ overlap at the $1 \mathrm{~m}^{2}$ scale to $26 \%$ overlap at the $1000 \mathrm{~m}^{2}$ scale. The conifer-broadleaf sites had the most total species in common with other types; $31 \%$ overlap and $39 \%$ overlap at the $1-\mathrm{m}^{2}$ and $1000-\mathrm{m}^{2}$ scales respectively (Table 8).

The overlap in the non-native flora across vegetation types showed similar patterns. The alder community had the most unique assemblage of non- 
native species at the $1 \mathrm{~m}^{2}\left(19 \%\right.$ overlap) and $1000 \mathrm{~m}^{2}$ ( $31 \%$ overlap) scales. At the $1000 \mathrm{~m}^{2}$ scale, the conifer-broadleaf community (also the most species rich) shared the most non-native species with other types ( $42 \%$ overlap, Table 8$)$.

Table 8. Species composition overlap at $1-\mathrm{m}^{2}$ and $1000-\mathrm{m}^{2}$ scales across five riparian vegetation types (based on the mean similarity, $J$, of pariwise comparisons of species lists from $1-\mathrm{m}^{2}$ subplots $(n=40)$ and $1000-\mathrm{m}^{2}$ plots $(n=4)$.

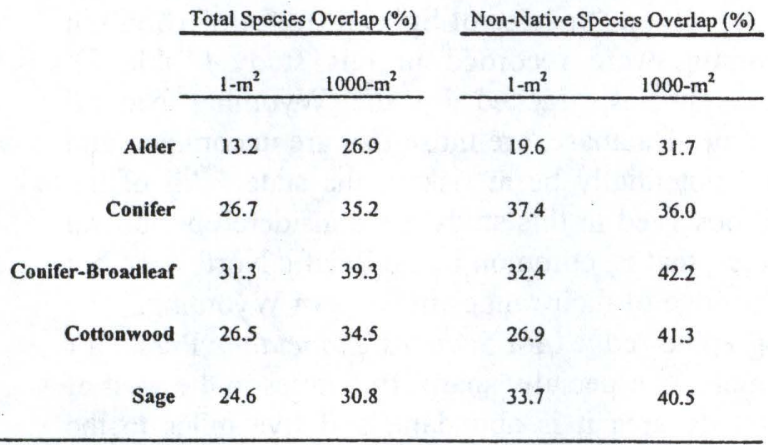

At the vegetation type scale, those communities with the most unique non-native species assemblages were the most invaded. A significant negative linear relationship was found between nonnative s pecies o verlap a nd p ercentage of non-native species $\left(r^{2}=0.97, P<0.002\right.$, Fig. 5), and this negative relationship was observed in the alder sites at each scale sampled (Fig. 6).

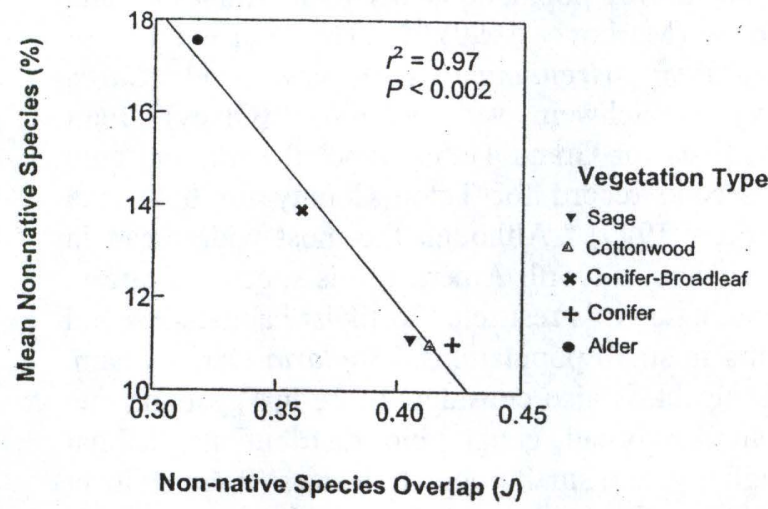

Figure 5 . Relationship non-native species overlap $(\Omega)$ to percentage of non-native species at vegetationtype scale (based on the mean similarity ( () of pairwise comparisons of species lists from four $1000-\mathrm{m}^{2}$

\section{$\uparrow$ DISCUSSION}

\section{Riparian Zone Species Richness}

Worldwide, studies of riparian vascular plants report unusually high levels of biodiversity (Décamps and Tabacchi 1994; Gregory et al. 1991; Planty-Tabacchi et al. 1996; Stohlgren et al. 1999;
Ward 1998). In this study, 294 total species were observed in 20 sample sites totaling 2 ha in area. The multi-scale sampling design captured $25.4 \%$ of approximately 1160 vascular plant species found in all of Teton County (Markow 1999; Shaw 1992). The dynamic nature of riparian landscapes (e.g., frequent flooding and mosaic landform) often leads to greater species richness than the surrounding upland communities. Studies from the Colorado Rockies and Central Grasslands (Stohlgren et al. 1998a), the Oregon Cascades (Gregory et al. 1991), and in Sweden (Nilsson et al. 1994) all reported higher species richness in riparian zones than in upslope habitats. However, studies reporting riparian vegetation to be relatively species poor do exist. In Western Australia, Hancock (1996) found that upland vegetation supported more species than riparian habitats. Enright et al. (1994) noted similar patterns in similar landscapes in Victoria, Australia.
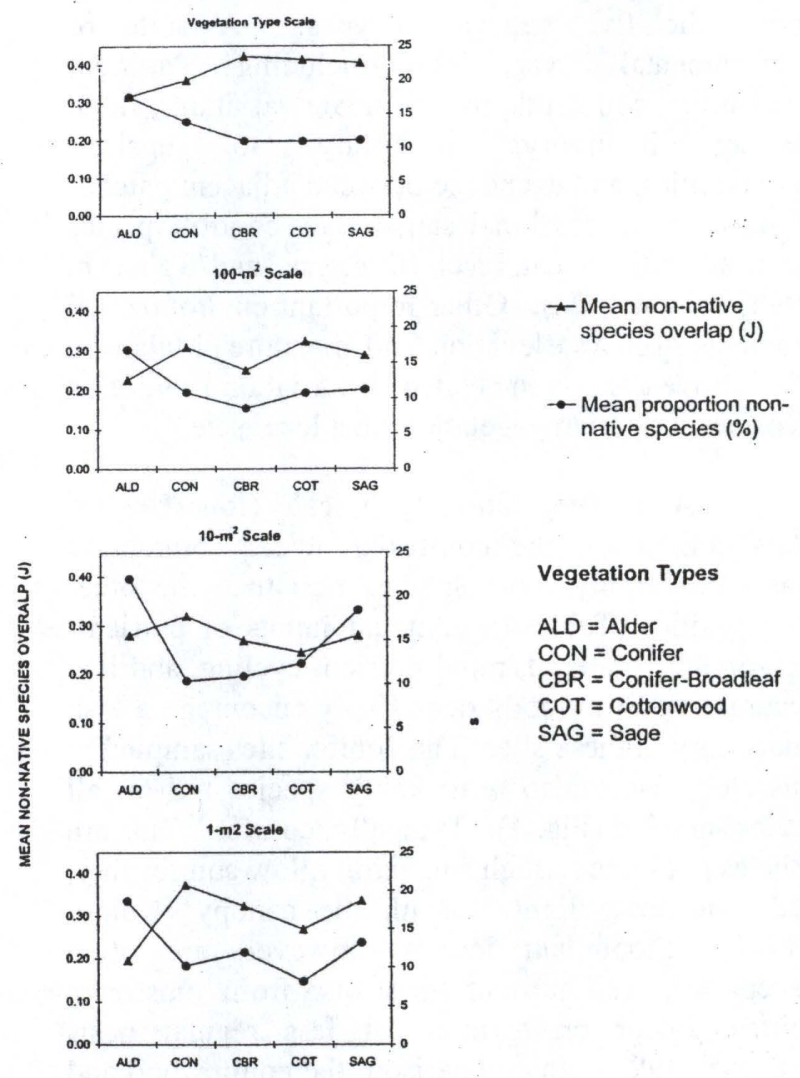

Vegetation Types

$A L D=$ Alder CON $=$ Conifer $\mathrm{CBR}=$ Conifer - Broadleaf COT $=$ Cottonwood $S A G=$ Sage

Figure 6 . Non-native species overlap $(J)$ and mean percentage of non-native speices scales across multiple in five riparian vegetation types (based on the mean similarity $(J)$ of pairwise comparisons of species lists at each scale).

Total species richness in the 20 sites varied from 42 species in the sage community to 96 species in the conifer-broadleaf community per 0.1 ha (Table 5). The overall mean species richness of 81.9 
species $/ 0.1$ ha is substantially higher than other studies report for riparian habitats in North America. Baker (1990) found an average total richness of 50.6 species/0.1 ha along the western face of the Colorado Rockies. His results are comparable to those from studies in Rocky Mountain National Park (Peet 1978) and the Santa Catalina Mountains in Arizona (Whittaker and Niering 1965). Total richness along ravines in the Finger Lakes region of New York averaged only 40 species/0.1 ha (Glenn-Lewin 1975). The size of the regional pool of species at the level of the river floodplain may influence the size of local assemblages of riparian species (Décamps and Tabacchi 1994). Additions of species from upstream protected areas and exchanges with surrounding upslope terraces may help explain the unusually high diversity in these Snake River riparian habitats.

\section{Species Richness: Comparisons Across Communities}

Total species richness varied considerably across the five vegetation types. A suite of environmental variables including nutrient availability, soil depth, microclimate variations, flood regime, herbivory, proximity to upslope communities, and exchange between adjacent patches of different successional stages may control species richness at the local level (Décamps and Tabacchi 1994; Knight 1994). Other important environmental gradients such a s e levation and moisture (Malanson 1993) have a lso b een r elated to $v$ ariation in species richness in riparian vegetation on a local sale.

At the vegetation type scale (four $1000 \mathrm{~m}^{2}$ plots combined), the conifer-broadleaf community was considerably more species rich than the other communities (Table 4). Annual inputs of nutrientrich organic material, rapid nutrient cycling, and low accumulation of woody debris may encourage a lush understory in these sites. The conifer sites sampled in this study were also remarkably species rich at all scales sampled (Fig. 1). Typically, conifer stands are species poor due to high soil acidity, low soil fertility, and inadequate light beneath the canopy (Knight 1994). Floodplain forests, however, are often exceptions, as nutrient deposits from upstream sources occur on a more or less regular basis (Markow 1999). In comparison, the cottonwood and alder sites were not remarkably rich at any scale. Cottonwood regeneration along the Snake River is in decline due to r egulated flows and extensive diking (Knight 1994). Selective harvesting of tree species by beaver (Castor canadensis) greatly affects community composition in riparian forests and shrublands, and may have led to the succession of Alnus species (Knight 1994). It is still unclear how successional trends in riparian landscapes operate and how they influence species richness.

\section{Wyoming Native Species of Special Concern}

Riparian communities have been recognized for their high level of species diversity, but little is known about regional endemics, taxa new to science, and uncommon species that may occur there (Wade 1999). Seven "Species of Special Concern" (SSC) in Wyoming were recorded in this study (Table 2). These species, tracked by the Wyoming Natural Diversity Database, are those that are uncommon and could potentially be at risk in the state. All of the SSC observed in this study are considered peripheral species, that is, common in the Pacific Northwest, but at the edge of their ranges in western Wyoming. The geographic "edge" for Sedum stenopetalum Pursh, for example, is especially sharp: five miles to the west of the study area it is abundant, and five miles to the east the species is absent (Markow 1999).

Several important plant collections were made as a result of this study. The collection of Torreyochloa pallida (Torr.) Church var. fernaldii (Hitchc.) Dore was only the second for the state of Wyoming. The only other specimen was collected in 1957, also near Moose, Wyoming. The occurrence of this species is strongly disjunct from the main portion of its range (Newfoundland to Minnesota), as there are no known populations between Minnesota and Moose (Markow 1999). The collections of Botrychium virgnianum (L.) Sw. and Carex deweyana Schwein var. bolanderi (Olney) Boott were firsts for Grand Teton National Park, and only the second record for Teton County for both taxa (Markow 1999). Although the most widespread in Botrychium in North America, this species is rare in Wyoming as it is restricted to moist habitat sites and occurs in small populations. Stellaria crispa Cham. \& Schlecht. is also considered rare in Wyoming due to similar broad geographic distributions, habitat specificity, and small population sizes (Rabinowitz et al. 1986). Carex deweyana var. bolanderi is one of the most common sedges in eastern Oregon, but, as a result of small local population sizes, is considered rare in Wyoming (Rabinowitz et al. 1986). Such sparsely distributed species are likely to be resilient to localized disturbance, but may be threatened under massive habitat destruction.

The SSC were recorded in all five vegetation types. Four species of concern were found in the conifer sites that were, cumulatively, the richest sites at all but the $1000 \mathrm{~m}^{2}$ scale. Three species recorded were unique to the alder 
community, which was relatively low in total species richness, but disproportionately high in exotic species richness (Figs. 4 and 5). Further research is needed demonstrate if these taxa of concern are a numerically important component of the riparian flora in Grand Teton National Park. Until more data are collected, conservation of known "Species of Special Concern", as well as those more critically threatened, will be best achieved through conservation of habitats in which they are found.

\section{Non-Native Invasions: Comparisons Across Communities}

Although riparian landscapes are documented areas of high biodiversity (Knight 1994; Malanson 1993; Naiman et al. 1993), there is increasing concern that these communities may also be easily invaded by non-native species. Environmental conditions that promote high species richness and occurrence of rare and endemic plants (e.g., low competitive displacement, infrequent major disturbance), may also allow the establishment and growth of non-native plants. Two-thirds of the Polish non-native flora was found in riverine habitats (Sykora 1990). DeFerrari et al. (1994) reported that non-native richness was $33 \%$ greater in riparian habitats than upland communities on the Olympic Peninsula in Washington state.

This study recorded 35 (11.9\% of total) nonnative species in five vegetation types comprising $26.9 \%$ of all non-native flora recognized in Teton County. These results are comparable with other studies investigating non-native riparian flora on the MacKenzie River in Oregon (30\%), the Adour River in France (24\%) (Planty-Tabacchi et al. 1996), and from data on the British flora (13-39\%; Crawley 1987). A study on non-native flora associated with Portuguese river systems, however, reported a relatively low level of invasion (6.2\%), but this figure was considered to be an underestimate because of the small sample area and location along the river corridor (Ferreira and Moreira 1995). Similar to the non-native flora observed in the Pacific Northwest (Planty-Tabacchi et al. 1996), all non-native species recorded in this study were herbaceous. Riparian communities in France, however, had a much higher rate of invasion by woody species (Planty-Tabacchi et al. 1996).

\footnotetext{
Overrepresented families of non-native species are usually associated with humans, particularly with their modern transportation systems and intensive landuse practices (Crawley 1987; Rutledge and McLendon; Tyser and Worley 1992,
}

Table 6). The plant families with the most nonnative representatives reported in this study (Asteraceae, Fabaceae, Poaceae) support this general observation. Non-native species in the genus Cirsium (Asteraceae) were introduced apparently as a contaminant of agricultural seed and for ornamental uses. Species in the genus Trifolium (Fabaceae) were introduced as forage plants, and species in the genus $P o a$ (Poaceae) were introduced for soil stabilization purposes. The spreading potential of these nonnative species is likewise related to human disturbance. Linear habitats such as roads, irrigation corridors, and pipelines usually contribute to easier spread of species through the landscape (Pysek and Prach 1994).

\section{Attributes of Non-Native Species Found in Riparian Communities}

Two main categories of non-native species have been described: (1) those that are mostly innocuous or do not affect community structure; and (2) those that interfere with some aspect of native species and community structure (Hancock et al. 1996; Randall 1996).

Non-native species described in the first criteria mix with, rather than replace native species and serve to increase species richness (Huston 1994). Numerous non-native species recorded in this study are likely having little overall effect on community structure or function, and are found widely throughout other native plant communities. Chenopodium album, a widespread annual forb, was found in two of the five vegetation types. Its occurrence in the conifer-broadleaf community (presence in three of four sites) may indicate fertile heavy soils with which it is typically associated. This plant is an effective competitor because of its rapid growth and removal of soil moisture. However, it has not been considered an aggressive or destructive plant (Rutledge and McLendon). Galium aparine, the fourth most abundant non-native plant observed overall, was concentrated in the alder and conifer communities. In the Pacific Northwest, this species has been observed to aggressively compete for water and nutrients, resulting in rapid growth and subsequent reduction in light levels for other species (Markow 1999). The cool climate characteristic of Grand Teton National Park appears to inhibit some of its competitive abilities. This may be one special case that demonstrates how the environment may influence whether introductions of non-native species will succeed. 
Several non-native species observed have the potential to dominate and change community form greatly from that of a "natural" one. Common features of these plants often include early season and rapid growth, vegetative reproduction, and efficiently dispersed propagules (Beerling 1995; Huston 1994). Several non-native species observed in this study exhibit these features. Poa pratensis, a wellestablished, widespread, adaptable European perennial grass, was the most abundant non-native species observed in this study. It was recorded in all five vegetation types with an average frequency of $67 \%$ across the 20 sample sites. Although favoring moist habitats, this plant is adapted to a wide range of environmental conditions. Because this species requires a relatively high nutrient content of soil substrate, its relatively low frequency in the conifer sites may indicate low soil fertility in those sites. In natural areas, this plant has the potential to invade and to modify native communities, and is able to compete most directly with cool season native grasses through rapid spreading by tillers and rhizomes (Rutledge and McLendon).

Phleum pratense, a cool-season, perennial bunchgrass (cultivated primarily as nutritious forage for domestic livestock), was observed in all five vegetation types. This species is considered to be an effective competitor and capable of forming selfperpetuating monocultures. Invasion of this species may inhibit conifer seedling establishment, attract non-native insects and animals, and increase fire potential (System 1996).

Taraxacum officinale Weber, one of the earliest spring bloomers on western rangelands, was the second most abundant non-native species observed in this study (mean frequency $50 \%$ ). Studies of the impact of this plant on native vegetation have been inconclusive. Agricultural studies have suggested that Taraxacum spp. can reduce the productivity of surrounding vegetation by $20 \%$ (Holm et al. 1997). However, a study with alfalfa reported no difference in productivity when dandelions were controlled. Lactuca oblongifolia, a "restricted noxious weed" (potentially detrimental) in Teton County, was widespread (present in three of four sites) in relatively low frequencies (mean frequency $\leq 11 \%$ ) in the alder community. Because of the relatively high potential for long distance seed dispersal characteristic of both $T$. officinale and $L$. oblongifolia, these two species have the potential to invade little disturbed or undisturbed native vegetation.

\section{Highly Disruptive Non-Native Species: A Priority for Conservation Management}

Several of the most highly disruptive nonnative species identified by the state of Wyoming and the National Park Service were recorded in this study (Table 3). Carduus nutans (present in all vegetation types) and Linaria vulgaris (present only in the alder) are classified as "Priority I" species by GTNP and noxious weeds by the state. These species are described as aggressive invaders that become established in small areas and expand into surrounding disturbed sites. Efficient seed dispersal primarily by wind, extensive seed-viability, and because Carduus nutans is unpalatable forage for wildlife and livestock, it is highly competitive in many habitats. L inaria vulgaris, most successful in moist, fertile conditions, is highly competitive due to extensive, creeping root systems and long distance seed dispersal achieved by winged seeds and water. Grand Teton National Park's primary control efforts include herbicides intended to stop the spread and reintroduction of these species and, eventually, eliminate them.

Cirsium vulgare, recorded in all alder sites and one conifer site, is a "Priority II" species. This category includes non-native species that have become established in small, localized areas, or have not been mapped. Seeds of this plant posses a hairy pappus and are well-suited for wind dispersal. Trampling and soil disturbance may also promote this highly competitive plant (Rutledge and McLendon). Large concentrations of ungulate and small mammal populations who use the alder communities along the Snake River may explain the relative abundance of Cirsium vulgare in this vegetation type. Current GTNP management efforts of "Priority II" taxa are oriented towards documenting the distribution and abundance of these species.

"Priority III" non-native species in GTNP include Cirsium arvense, Tragopogon dubius, and Melilotus officinalis, and are known to have invaded the GTNP and require extensive control. Only Tragopogon dubius was observed in the sample plots at moderate frequencies (mean frequency $24 \%$ ), primarily concentrated in the cottonwood and sage sites possibly reflecting its preference for drier sites. Melilotus officinalis, introduced as a forage plant and now widespread, was observed at low frequencies (mean frequency $\leq 13 \%$ ) in all five communities. Its consistent occurrence across the conifer sites suggests patchy microsite conditions which allow sufficient light into the understory, as this species is generally intolerant of dense shade. Long-lived seeds 
with dispersal by wind and water allow this species to readily invade open areas. Cirsium arvense, long recognized as an agricultural pest, has recently been recognized as harmful to natural areas as well. The alder community was significantly invaded by this species, with an average frequency of $39 \%$ for three sites, and as much as $71 \%$ in the most invaded plot. Disturbance, minimal competition, and adequate light are required for initial establishment, which explains it's abundance in open areas, including wetlands. But once established, reproduction by creeping roots contributes to localized spread, and wind dispersed seeds promote dispersal over longer distances. Eradication efforts of "Priority III" species are considered beyond the GTNP's current staffing and funding capabilities.

\section{Non-Native Invasions in Riparian Communities: Conservation Concerns}

The results of this study suggest that the riparian flora of Grand Teton National park is becoming infected with non-native species. Overall, non-native species were found in small populations either widely dispersed across the five vegetation types or appearing to have some level of habitat specificity. Several species observed are designated noxious weeds that have the potential to alter community structure, associated nutrient cycles and disturbance regimes, as well as displace native species. Long term consequences of invasions include loss of native diversity that may have negative effects on native animal species that use these riparian communities to meet particular food and habitat requirements.

Riparian zones play a potentially important role within landscapes as corridors facilitating the dispersal of plants, including adaptable and aggressive non-native species (DeFerrari and Naiman 1994). Beerling (1995) confirmed the importance of river flows in extending plant distributions by documenting a strong correlation between the range extension of a plant and the previous year's rainfall.

Invasions are also facilitated by enormous and continuous seed sources through human transportation and land-use practices (Stohlgren et al. 1999). The collection of Veronica officinalis L. in this study represented the first documentation of this non-native species occurring in the state (Markow 1999). This species was observed again a few months after my initial collection along a road corridor several miles from my study area. This pattern may be consistent with other models of species invasions where a non-native species progressively spreads from its point of introduction, in this case possibly roadside areas (Tyser and Worley 1992). Human-made corridors may also facilitate repeated introductions that may allow some species to persist which would otherwise be eradicated in the longer term by environmental hazards (Newsome and Noble 1986). But as Huston (1994) cautions: "Arrival is not invasion." Transport and introduction of a species is just the first step of a successful invasion. Much more research is needed to provide insights into the seemingly complex biological processes underlying successful invasions.

The presence and persistence of large numbers of both innocuous and noxious non-native species in this representative sample of five riparian vegetation types demonstrates the efficiency with which plants are establishing and spreading within protected areas. Managers should recognize that Grand Teton National Park and other conservation areas specified for the long-term preservation of species and habitats are not safe from invasion. Activities such as regulating stream flow and dike construction, road building, and livestock grazing may be negatively influencing the health of native communities. The connectivity of natural and artificial corridors may have profound negative affects with regard to non-native plant dispersal despite the well known benefits the connectivity provides for migratory and habitat corridors (Primack 1993; Stohlgren et al. 1998a).

\section{Species Richness and Invasibility: The Debate Continues}

Overall, the results of this study demonstrate a positive relationship between species richness and non-native invasion across the five vegetation types. At the smallest $\left(1-\mathrm{m}^{2}\right)$ and largest $\left(1000-\mathrm{m}^{2}\right)$ scale sampled, a significant linear relationship was found between the total number of species and number of nonnative species. Studies from the Colorado Rockies (Stohlgren et al. 1999), France (Planty-Tabacchi et al. 1996), and California (Kruger et al. 1989) have also described a positive relationship between total species richness and non-native invasion. Studies from Australia, however, found a higher percentage of non-native species in species-poor vegetation communities (Fox and Fox 1986). It remains controversial how the maintenance of species rich communities influences resistance to invasion.

\section{Alder Ecosystem Effects on Non-Native Invasions}

Field observations and statistical analyses from this study suggest that the alder community is 
an exception to the positive relationship between species richness and invasibility demonstrated in the four other vegetation types. At all scales sampled, the alder sites were not relatively species rich, yet were highly and disproportionately invaded ( $\geq 16 \%)$, often more than double that of other communities. High levels of invasion in alder communities have been documented elsewhere. Alder flats in the Hoh watershed on the Olympic Peninsula, for example, had the highest cover of non-native species of six landscape patch-types sampled (DeFerrari and Naiman 1994). In contrast to this study, high species richness was observed in alder stands on alluvial sites on the Olympic Peninsula as compared to conifer stands (Sharpe 1956 as cited in Franklin and Pechanec 1968).

Data from the alder sites sampled in this study suggest that non-native invasion, in this particular vegetation type, is not strongly influenced by species richness. Some mathematical models point to community-level rather than invader-level properties as the strongest determinant of differences in invasion success (Case 1990). Site-specific factors such as vegetational composition, disturbance regime, and soil characteristics are thought to affect non-native flora (Tyser and Worley 1992). What environmental conditions of the alder sites might support these invasions? Several studies have indicated that alder functions to improve soil nutrient content. Tarrant (1968) demonstrated that the degree of nitrogen fixation in the root nodules of alder considerably exceeds that of legume nodules. Alder may also be particularly effective as a nitrogen-fixer when soil nitrogen is low. This suggests that alder can grow vigorously on infertile soils and simultaneously fertilize them. Additionally, the nitrogen content of alder leaves has been shown to be substantially higher than that of other needle-leaved and broadleaved trees (Yamaya 1968). Due to rapid growth and rapid decomposition of nitrogen-rich litter, the rate of nutrient cycling under alder forests is considered to be faster than in many other forest types (Yamaya 1968).

Alnus species may be providing an important source of nitrogen for plants in the Snake River floodplain, which is especially important in cool climates. Evidence suggests that nutrient enrichment may alter ecosystem level properties in ways that may encourage invasion of non-native species. Maron and Connors (1995) reported that within a California coastal prairie, a nitrogen-fixing shrub (Lupinus arboreus Sims) facilitated invasions of prairie plant communities by non-native grasses and forbs. More importantly, the nitrogen enrichment and soil fertility observed in these habitats resulted in a highly productive but relatively species-poor community dominated primarily by non-native grasses (Maron and Connors 1995). The mechanism of nitrogen-fixation may be promoting non-native invasions in the alder vegetation type by altering competitive interactions, and favoring those plants which have the ability to utilize enhanced soil fertility and execute superior colonizing abilities.

\section{Habitat Specific Non-Native Species: Invader-Level Properties}

In addition to the characteristics of the recipient habitats, patterns of invasion are also determined by the biological and physiological attributes of the species relating to dispersal capabilities and ability to compete with native flora (Pysek and Prach 1994). The alder community, the most invaded vegetation type in this study, had the most unique assemblage of total and non-native species when compared to the other four vegetation types. Similar results were described in riparian habitats of the Rocky Mountains of Colorado (Stohlgren et al. 1999). These studies provide evidence that not only the richest plant communities, but those with the most distinct assemblages are alarmingly vulnerable to invasion.

Almost one-third (6 species) of the nonnative species recorded in the alder sites were unique to this vegetation type (Table 7). DeFerrari et al. (1994) also reported that the occurrence of some nonnative species were highly correlated with landscape patch-type. When the occurrence of a species is concentrated into one or more habitat types, it is assumed to reflect some level of ecological specialization of the species and indicates that invasion is somehow limited by the characteristics of the recipient habitat (Pysek and Prach 1994). Many of the non-native species specific to the alder sites, however, have very effective reproductive and dispersal strategies (e.g., high seed abundance, wind and water seed dispersal, creeping rhizomes, early flowering). The relatively low frequencies in which they were observed in this study suggest that time may play an important role in our view of the species' habitat preferences or its "success" as an invader. Depending upon life history characteristics and time of introduction, a species may be limited to a particular site for several years and then massively invade new surrounding habitats.

What these patterns suggest is that there is some relationship between properties of an invading species and the properties of the community that it 
invades. Using the patterns that emerge from ecological and biogeographical studies, future research should emphasize the important characteristics of both non-native species and the target community to uncover the biological processes that underlie non-native invasions.

\section{Patterns of Non-Native Invasions: Effects of Scale}

It has been widely noted that vegetationenvironment interactions and plant community structure are scale specific (Pollock et al. 1998). Of particular importance in riparian zones are environmental gradients which spatially segregate species (Ward 1998). A recent study from the Colorado Rockies and Central Grasslands demonstrated that patterns of invasibility depend both upon spatial scale and vegetation type (Stohlgren et al. 1999). Results from this study are mixed, and prevent generalization about non-native invasion patterns in Snake River riparian communities. Patterns of richness were scale-dependant. Significant differences in total, native, and non-native richness across communities were poorly detected at the $1-\mathrm{m}^{2}$ scale and, expectedly, more pronounced at the $1000-\mathrm{m}^{2}$ scale. The positive relationship between species richness and invasion was, conversely, not scale dependent. Extrapolation to the vegetation type scale may be problematic as the number of sample plots used in statistical analysis becomes quite small. More replicate plots in each vegetation type may be necessary to more completely describe richness and invasion at the $1000-\mathrm{m}^{2}$ scale before using them to describe landscape-level phenomena. What remains largely unresolved, is which factors are responsible for spatial variation in species richness on different scales (Baker 1990).

\section{IMPLICATIONS FOR MANAGEMENT AND CONSERVATION}

Non-native species invasions directly interfere with the major National Park Service management goal of protecting native biota. Because the results of this study suggest species rich riparian landscapes are vulnerable to non-native invasions in Grand Teton National Park, the following recommendations are offered to help managers respond efficiently to this conservation priority.

\section{Vegetation Sampling}

- Measure both habitat (e.g., frequency/duration of flooding, channel morphology, water quality, vegetation composition, foliar cover and production) and population parameters (e.g., distribution, density and diversity of plants) at multiple scales. The key to understanding patterns of diversity is to understand which processes are important for particular species at particular scales (Pollock et al. 1998).

- Sample vegetation with goal of estimating the potential effects (e.g., displacement, hybridization) of non-native species on native plant communities.

As resources and time are limiting, this approach allows managers to identify and target nonnative species which pose an immediate threat the native species and communities, and give species which have small potential impact a lower priority for management (Rutledge and McLendon).

\section{Vegetation Monitoring}

- Establish long-terms plots for monitoring.

This will facilitate monitoring of current distributions of non-native species and provide a systematic surveillance system to provide early warning of new invading species (Rutledge and McLendon). Careful monitoring of the density, distribution, and diversity of plants will assist in determining how each non-native species should be controlled.

- Monitor different vectors of invasion (e.g., roads, livestock grazing, rivers).

Communities in close proximity to large sources of potential invaders often have noted more non-native species than those communities more isolated from sources of invading species (Crawley 1987; Tyser and Worley 1992).

\section{Management of Non-Native Species Invasions}

- Sponsor further research on predicting which species will become invasive so policies can work to eradicate them (Randall 1996).

A set of unifying management priorities should be developed to be used a priori to identify whether a particular species will become invasive (Beerling 1995).

- Closely examine control measures to determine potential side effects on non-target species. 
Control measures used to minimize negative impact to a wide range of non-target species often require labor-intensive methods like handpulling of specific plants. Grand Teton National Park could benefit from using volunteer crews and community members to accomplish early detection and elimination of certain non-native species.

\section{CONCLUSIONS}

Five riparian vegetation types sampled along the Snake River are threatened by non-native invasions. Specifically, the alder community appears to be most at risk. Studies have consistently reported that in riparian zones substantially altered by humans, $25-30 \%$ of the flora is considered non-native (DeFerrari and Naiman 1994). This study reports a lower figure $(11.9 \%)$ for a disproportionately small area in a relatively undisturbed site of Grand Teton National Park. Of the approximately 130 non-native species known in Teton County, 26.9\% were recorded in this study. Non-native species may be displacing or eliminating native and rare species in these riparian habitats, the net result being reduction in overall species diversity and a simplified ecosystem (Beerling 1995; Crawley 1987; Ferreira and Moreira 1995; Randall 1996; Rejmanek 1995).

Current evidence suggests that simple communities are less persistent than complex ones (Beerling 1995). Nearly all human influences on riparian landscapes (dams, diking, irrigation) have already simplified these systems (Naiman et al. 1993; Rutledge and McLendon). The indirect, unintentional, or accidental introduction of nonnative species may serve to further simplify these ecologically and culturally significant landscapes and ultimately reduce local and regional biodiversity.

\section{$\uparrow \quad$ LITERATURE CITED}

Baker, W. L. 1990. Species richness of Colorado riparian vegetation. Journal of Vegetation Science 1:119-124.

Beerling, D. J. 1995. General aspects of plant invasions: An overview. in P. Pysek, K. Prach, M. Rejmanek, and M. Wade, eds. Plant Invasions - General Aspects and Special Problems. SPB Academic Publishing, Amsterdam, 237-247.
Case, T. J. 1990. Invasion resistance arises in strongly interacting species-rich model competition communities. Proceedings of the National Academy of Science 87:96109614.

Crawley, M. J. 1987. What makes a community invasible? in A. J. Gray, M. J. Crawley, and P. J. Edwards, eds. Colonization, Succession, and Stability. Blackwell, Oxford, 429-453.

Décamps, H., and Tabacchi, E. 1994. Species richness in vegetation along river margins. in P. S. Giller, A. G. Hildrew, and D. Raffealli, eds. Aquatic Ecology - Pattern, Process, and Scale. Blackwell, Oxford, 121.

DeFerrari, C. M., and Naiman, R. J. 1994. A multiscale assessment of the occurrence of exotic plants on the Olympic Peninsula, Washington. Journal of Vegetation Science 5:247-258.

Dorn, R. D. 1992. Vascular Plants of Wyoming. Mountain West Publishing, Cheyenne, Wyoming.

Elton, C. S. 1958. The ecology of invasions by animals and plants. Chapman and Hall, Ltd., London.

Enright, N. J., Miller, B. P., and Crawford, D. 1994. Environmental correlates of vegetation patterns and species richness in the northern Grampians, Victoria. Australian Journal of Ecology 19:159-168.

Ferreira, M. T., and Moreira, I. S. 1995. The invasive component of a river flora under the influence of Mediterranean agricultural systems. in P. Pysek, K. Prach, M. Rejmanek, and M. Wade, eds. Plant Invasions - General Aspects and Special Problems. SPB Academic Publishing, Amsterdam, 117-127.

Fox, M. D., and Fox, B. J. 1986. The susceptibility of natural communities to invasion. in $\mathrm{R}$. H. Groves and J. J. Burdon, eds. Ecology of Biological Invasions. Cambridge University Press, Cambridge, 57-66. 
Franklin, J. F., and Pechanec, A. A. 1968. Comparison of vegetation in adjacent alder, conifer, and mixed alder-conifer communities: Understory vegetation and stand structure. Biology of Alder. Pacific Northwest Forest and Range Experiment Station, Forest Service, U.S. Department of Agriculture, Portland, Oregon, 36-44.

Glenn-Lewin, D. C. 1975. Plant species diversity in ravines of the southern Finger Lakes region, New York. Canadian Journal of Botany 53:1465-1472.

Gregory, S. V., Swanson, F. J., McKee, W. A., and K.W., C. 1991. An ecosystem perspective of riparian zones. BioScience 41:540-551.

Hancock, C. N., Ladd, P. G., and Froend, R. H. 1996. Biodiversity and management of riparian vegetation in Western Australia. Forest Ecology and Management 85:239250.

Hitchcock, C. L., and Cronquist, A. 1 973. Flora of the Pacific Northwest; an illustrated manual. University of Washington Press, Seattle.

Holm, L., Doll, J., Holm, E., Pancho, J., and Herberger, J. 1997. World weeds: natural histories and distributions. John Wiley and Sons, New York.

Huston, M. A. 1994. Biological Diversity: The Coexistence of Species in Changing Landscapes. Cambridge University Press, New York, USA.

Knight, D. H. 1994. Mountains and Plains: The Ecology of Wyoming Landscapes. Yale University Press, New Haven.

Kruger, F. J., Breitenbach, I. A., Macdonald, W., and Richardson, D. M. 1989. The characteristics of invaded Mediterraneanclimate regions. in J. A. Drake et. al., eds. Biological Invasions: A Global Perspective. John Wiley \& Sons, Chichester, UK, 181213.

Malanson, G. P. 1993. Riparian Landscapes. Cambridge University Press, Cambridge.

Markow, S. 1999. Botanist, Rocky Mountain Herbarium, University of Wyoming, Laramie.
Maron, J. L., and Connors, P. G. 1995. A native nitrogen-fixing shrub facilitates weed invasion. Oecologia 105:302-312.

Naiman, R. J., Décamps, H., and Pollock, M. 1993. The role of riparian corridors in maintaining regional biodiversity. Ecological Applications 3:209-212.

Nelson, B. E., and Hartman, R. L. 1997. Checklist of the Vascular Plants of Wyoming. Rocky Mountain Herbarium, University of Wyoming, Laramie.

Newsome, A. E., and Noble, I. R. 1986. Ecological and physiological characters of invading species. in R. H. Groves and J. J. Burdon, eds. Ecology of Biological Invasions. Cambridge University Press, Cambridge, 10-17.

Nilsson, C., Ekblad, A., Cynesius, M. A., Backe, S., Gardfjell, M., Carlberf, B., Hellqvist, S., and Jansson, R. 1994. A comparison of species richness and traits of riparian plants between main river channel and its tributaries. Journal of Ecology 82:281-298.

Peet, R. K. 1978. Forest vegetation of the Colorado Front Range: Patterns of species diversity. Vegetatio 37:65-78.

Planty-Tabacchi, A., Tabacchi, E., Naiman, R. J., Deferrari, C., and Décamps, H. 1996. Invasibility of species-rich communities in riparian zones. Conservation Biology 10:598-607.

Pollock, M., Naiman, R., and Hanley, T. 1998. Plant species richness in riparian wetlands - a test of biodiversity theory. Ecology 79:94-105.

Primack, R. B. 1993. Essentials of Conservation Biology. Sinauer Associates, Sunderland, Massachusetts.

Pysek, P., and Prach, K. 1994. How important are rivers for supporting plant invasions? in $\mathrm{L}$. C. de Waal, L. E. Child, P. M. Wade, and J. H. Brock, eds. Ecology and Management of Invasive Riverside Plants. John Wiley \& Sons Ltd., New York, 19-26. 
Rabinowitz, D., Cairns, S., and Dillon, T. 1986. Seven forms of rarity and their frequency in the flora of the British Isles. in $\mathrm{M}$. E. Soule, ed. Conservation Biology: the science of scarcity and diversity. Sinauer Associates, Sunderland, Massachusetts, 182204.

Randall, J. M. 1996. Weed control for the preservation of biological diversity. Weed Technology 10:370-383.

Rejmanek, M. 1995. What makes a species invasive? in P. Pysek, K. Prach, M. Rejmanek, and M. Wade, eds. Plant Invasions - General Aspects and Special Problems. SPB Academic Publishing, Amsterdam, 3-13.

Rutledge, C. R., and McLendon, T. (no year) An assessment of exotic plant species of Rocky Mountain National Park. Department of Rangeland Ecosystem Science, Colorado State University.

Sharpe, G. W. 1956. A taxonomical-ecological study of the vegetation by habitats in eight forest types of the Olympic rain forest, Olympic National Park, Washington. Ph.D. thesis, University of Washington, Seattle.

Shaw, R. 1992. Annotated checklist of the vascular plants of Grand Teton National Park and Teton County, Wyoming. Grand Teton National History Association, Moose, Wyoming.

Stohlgren, T. J., Binkley, D., Chong, G. W., Kalkhan, M. A., Schell, L. D., Bull, K. A., Otsuki, Y., Newman, G., Bashkin, M., and Son, Y. 1999. Exotic plant species invade hot spots of native plant diversity. Ecological Monographs 69:25-46.

Stohlgren, T. J., Bull, K. A., Otsuki, Y., Villa, C. A., and Lee, M. 1998a. Riparian zones as havens for exotic plant species in the central grasslands. Plant Ecology 138:113-125.

Stohlgren, T. J., Bull, K. A., and Otsuki, Y. 1998b. Comparison of rangeland vegetation sampling techniques in the Central Grasslands. Journal of Range Management 51:164-172.
Stohlgren, T. J., Chong, G. W., Kalkhan, M. A., and Schell, L. D. 1997. Rapid assessment of plant diversity patterns: a methodology for landscapes. Environmental Monitoring and Assessment 48:25-43.

Stohlgren, T. J., Falkner, M. B., and Schell, L. D. 1995. A Modified-Whittaker nested vegetation sampling method. Vegetatio 117:113-121.

Sykora, K. V. 1990. History of the impact of man on the distribution of plant species. in $\mathrm{F}$. Di Castri, A. J. Hasen, and M. Debussche, eds. Biological Invasions in Europe and the Mediterranean Basin. Kluwer Academic Publishers, Dordrecht, Holland, 37-50.

System, F. E. I. 1996. Prescribed Fire and Fire Effects Research Work Unit, Rocky Mountain Research Station.

Tarrant, R. F. 1968. Some effects of alder on the forest environment. Biology of Alder. Pacific Northwest Forest and Range Experiment Station, Forest Service, U.S. Department of Agriculture, Portland, Oregon, 193.

Tilman, D. 1997. Community invasibility, recruitment limitation, and grassland biodiversity. Ecology 78:81-92.

Tyser, R. W., and Worley, C. A. 1992. Alien flora in grasslands adjacent to road and trail corridors in Glacier National Park, Montana (U.S.A.). Conservation Biology 6:253-262.

Wade, K. 1999. A superintendent speaks out on the value of inventory and monitoring. Park Science.

Ward, J. V. 1998. Riverine landscapes: biodiversity patterns, disturbance regimes, and aquatic conservation. Biological Conservation 83:269-278.

Whittaker, R. H., and Niering, W. A. 1965. Vegetation of the Santa Catalina Mountains, Arizona: A gradient analysis of the south slope. Ecology $46429-452$.

Wilkinson, L. 1997. SYSTAT version 7.0. SPSS, Inc. Chicago, Illinois. 
Yamaya, K. 1968. On the influence of alder (Alnus inokumae) on soil properties in northern Japan. Biology of Alder. Pacific Northwest Forest and Range Experiment Station, Forest Service, U.S. Department of Agriculture, Portland, Oregon, 197-205. 